\title{
COMPOSITION EN ACIDES AMINÉS DES MATIÈRES AZOTÉES DU CONTENU DUODÉNAI DU RUMINANT
}

\author{
C. CHAMPREDON, R. PION et P. THIVEND * \\ Station d'Études des Métabolismes, \\ * Station de Recherches sur l'Élevage des Ruminants, \\ Centre de Recherches de Clermont-Ferrand, I. N. R. A., \\ 63 - Saint-Genès-Champanelle
}

Nous avons étudié la composition en acides aminés des matières azotées du contenu digestif chez des jeunes bovins ( $300 \mathrm{~kg}$ ) munis de doubles canules du duodénum.

Au cours d'une première expérience, nous avons étudié l'évolution postprandiale de la composition en acides aminés des contenus prélevés pendant $\mathbf{r} 2$ heures consécutives. Les échantillons ont été regroupés par périodes de 3 heures. Nous avons séparé la fraction soluble dans l'acide trichloracétique à Io $\mathrm{p}$. Ioo du résidu d'extraction. Les extraits et les résidus ont ensuite été hydrolysés par l'acide chlorhydrique $6 \mathrm{~N}$ en vue du dosage des acides aminés. Les variations des compositions au cours de la journée sont faibles, surtout en ce qui concerne les résidus d'extraction. Les compositions en acides aminés des fractions acidosolubles ne sont pas très différentes de celles des résidus d'extraction, contrairement à ce que l'on observe pour les aliments ingérés. Cependant, les extraits sont nettement plus riches en acide glutamique, ce qui est compensé par des teneurs plus faibles de la plupart des autres acides aminés.

Nous avons étudié ultérieurement la composition en acides aminés des matières azotées de contenus de duodénum de bovins recevant des rations très différentes (ensilage de maïs-urée, et herbe). Les compositions en acides aminés totaux, déterminées après hydrolyse des échantillons, sont voisines pour les trois types de régimes. Toutefois les contenus de duodénum des animaux qui ont reçu des aliments contenant de l'urée sont plus riches en phénylalanine et en acide glutamique. Les teneurs en lysine identiques pour tous les régimes, correspondent en fait à une proportion dans l'ensemble des acides aminés légèrement plus élevée dans le cas des rations à base d'herbe que dans celui des autres régimes ; en effet, la part dans l'azote total de l'échantillon, de l'azote correspondant à l'ensemble des acides aminés dosés, est un peu plus faible dans le premier cas que dans le second.

Si les quantités de matières azotées qui arrivent dans l'intestin grêle des ruminants peuvent varier au cours de la journée, leur composition en acides aminés reste sensiblement constante même avec des régimes très différents ce qui traduit l'importance du rôle régulateur du rumen.

\section{SUMMARY}

\section{AMINO ACID COMPOSITION OF THE NITROGENOUS MATTER OF THE DUODENAL CONTENT IN RUMINANTS}

The aim of our experiment was to study the amino acid composition of the nitrogenous matter in the digesta of young cattle fitted with re-entrant duodenum cannulae. 
During the first trial, we examined the postprandial amino acid composition of the contents collected during I 2 consecutive hours. The samples collected during 3 hours were pooled together. The ro p. Ioo trichloracetic acid soluble fraction was separated from the residue. The extracts and residues were then hydrolyzed by $6 \mathrm{~N}$ hydrochloric acid for the amino acid determination. Variations in the amino acid compositions during the day are low, especially as regards the extraction residues. The amino acid compositions of the acidosoluble fractions are not very different from those of the extraction residues, in contrast to what is observed in the ingested food. However, nitrogenous compounds of the extracts contain more glutamic acid, and consecutively less of most of the other amino acids than those of the residues.

Moreover, we studied the amino acid composition of the nitrogenous matter of the duodenum contents of cattle receiving diets differing widely one from the other (maize-urea silage, hay-barley-urea, and grass). The total amino acid compositions determined after hydrolysis of the samples are similar for the three kinds of diets. However, the duodenum contents of the animals which received diets with urea, contain more phenylalanine and glutamic acid. The Iysine content is identical for all the diets, but its proportion among the other amino acids is slightly higher in the case of the grass diet than for the other diets.

The amounts of nitrogenous matter leaving the abomasum may vary during the day, but their amino acid composition remains fairly constant even with very different diets, a fact which shows the importance of the regulatory role of the rumen.

\title{
UTILISATION COMPARÉE DU CARBONATE ET DU SULFATE DE CALCIUM CHEZ LE MOTTON
}

\author{
L. GUÉGUEN et P. BESANÇON \\ Station de Recherches de Nutrition, \\ Centre national de Recherches zootechniques, I. N. R. A., \\ 78 - Jouy-en-Josas
}

L'expérience que nous rapportons fait partie d'un programme général de recherches sur l'influence de divers facteurs alimentaires sur le métabolisme phospho-calcique chez l'animal et fournit les premiers résultats d'une étude portant sur l'influence des sulfates.

L'emploi de plus en plus fréquent de régimes à base d'ensilage de mais et d'urée chez les ruminants nécessite un supplément de soufre et de calcium et l'apport de sulfate de calcium pourrait être envisagé. Chez l'Homme, ce sel serait très mal absorbé (LeSTradeT, 1962). En fait, il a été démontré chez le Rat (CAUSERET et Hugot, I958) que l'absorption du calcium ainsi fourni était normale mais que l'excrétion urinaire était accrue, sans toutefois diminuer le bilan calcique.

Le présent essai a porté sur 3 moutons mâles pesant de 50 à $60 \mathrm{~kg}$, recevant une ration de base pauvre en calcium ( $\mathrm{I} g$ par $\mathrm{kg}$ de matière sèche), supplémentée soit avec $\mathrm{CaCO}_{3}$, soit avec $\mathrm{CaSO}_{4}$. Les aliments ainsi complétés contenaient en moyenne $5 \mathrm{~g}$ de $\mathrm{Ca}, 3,8 \mathrm{~g}$ de $\mathrm{P}$ et $\mathrm{I}, 2$ ou $4 \mathrm{~g}$ de $\mathrm{S}$ par $\mathrm{kg}$. Pour chaque régime, deux périodes de bilans de ro jours ont été réalisées, dont une avec dilution isotopique $\left({ }^{45} \mathrm{Ca}\right)$.

Les coefficients d'utilisation digestive réelle (CUDr) de Ca sont de 23,8 p. Ioo pour le car- 